\title{
HUBUNGAN KARAKTERISTIK PEGAWAI PEMERINTAH DAERAH DAN IMPLEMENTASI SISTEM PENGUKURAN KINERJA: PERSPEKTIF ISMORFISMA INSTITUSIONAL
}

\author{
Hafiez Sofyani* \\ Prodi Akuntansi Universitas Muhammadiyah Yogyakarta, Indonesia \\ e-mail: hafiez.sofyani@umy.ac.id \\ Rusdi Akbar \\ Prodi Akuntansi Universitas Gadjah Mada, Indonesia \\ e-mail: rusdi.aknar@ugm.ac.edu
}

\begin{abstract}
The purpose of this study is to examine the association of individual characteristics of local government toward the implementation of performance measurement systems (PMS). In addition, this study will also investigate the institutional isomophism phenomenon which occurs related to the PMS implementation. The study employs a mixed methods approach i.e. two-stage sequential explanatory. The first stage was hypothesis testing using Structural Equation Modeling (SEM), and the second stage using deductive thematic analysis. The study find that self-efficacy and conscientiousness trait associated with PMS implementation. Then, PMS impelementation is triggered and triggering different isomorphism phenomenon i.e. coercive, mimetic and normative.
\end{abstract}
Keywords: Employee Characteristics, Performance Measurement System, Institutional Isomorphism http://dx.doi.org/10.20885/jaai.vol19.iss2.art6

\begin{abstract}
Abstrak
Tujuan penelitian ini untuk menguji hubungan karakteristik pemerintah daerah menuju penerapan performance measurement systems (PMS). Penelitian ini juga menginvestigasi fenomena isomorfisma institusional yang berhubungan dengan penerapan PMS. Penelitian ini menggunakan pendekatan metode campuran seperti two-stage sequential explanatory. Langkah pertama menguji hipotesis menggunakan Structural Equation Modeling (SEM), dan langkah kedua menggunakan deductive thematic analysis. Penelitian ini menemukan self-efficacy dan conscientiousness berhubungan denganpenerapan PMS. Kemudian, penerapan PMS dipicu dan memicu fenomena isomorfisma yang berbeda seperti koersif, mimetic dan normatif.
\end{abstract}

Katakunci: Karakteristik Karyawan, PMS, Isomorfisma Institusional

\section{PENDAHULUAN}

Isu kinerja dan sistem pengukuran kinerja di ranah sektor publik, khususnya lembaga pemerintahan masih menjada topik hangat penelitian (Ittner et al. 2002; Sofyani dan Akbar 2013). Di Indonesia sendiri kajian kinerja masih menjadi tugas rumah dari Badan Pemeriksa Keuangan selaku lembaga yang terlibat dalam pengembangan instrument sistem pengukuran kinerja. Sampai hari ini, banyak lembaga pemerintahan, khususnya pemerintah daerah, yang hanya berfokus pada upaya pencapaian kinerja keuangan dan upaya memperoleh opini audit "wajar". Padahal, karakteristik lembaga sektor publik yang notabene nirlaba, seharusnya lebih mengutamakan outcome dan impact dari suatu operasional yang diselenggarakan oleh organisasi daripada aspek keuangan.

Di Indonesia isu menyangkut sistem pengukuran kinerja di lembaga pemerintah, 
baik pusat maupun daerah, mulai diatur semenjak dikeluarkannya Instruksi Presiden (Inpres) Nomor 7 tahun 1999. Inpres tersebut mengisyaratkan untuk diterapkannya Sistem Akuntabilitas Kinerja Instansi Pemerintah (SAKIP) guna meningkatkan akuntabilitas dan kinerja pemerintah di Indonesia. Dalam perjalanannya, implementasi sistem pengukuran kinerja ini berjalan tidak sesuai harapan. Dalam laporan yang diunggah di situs Kementerian Pendayagunaan Aparatur Negara dan Reformasi Birokrasi mengenai pelaporan akuntabilitas kinerja, dari semua pemerintah daerah di Indonesia tahun 2010, hanya terdapat 9 (sembilan) pemerintah provinsi dan 5 (lima) kabupaten/kota yang dinilai B (baik). Sedangkan pemerintah daerah yang mendapat predikat CC (cukup baik) ada sekitar 16,27 persen dari total 29 provinsi dan 57 kabupaten/kota yang dievaluasi. Capaian ini tidak sesuai dengan target yang telah ditetapkan yakni sekitar 20 persen pemerintah daerah mendapat penilaian akuntabilitas kinerja CC (cukup baik). Pada tahun 2012, terjadi penurunan pada kabupaten yang memperoleh predikat B (baik), yakni hanya 2 (dua) kabupaten saja, yaitu; Sukabumi dan Sleman, dan 104 (23,74 persen) kabupaten/kota yang mendapatkan predikat CC (cukup baik) dari total 438 kabupaten/kota yang dievaluasi (www.menpan.go.id).

Dari berbagai permasalahan yang muncul terkait implementasi sistem pengukuran kinerja tersebut, maka banyak pula riset-riset yang mengangkat isu sistem pengukuran kinerja yang didasarkan pada teori organisasi (Pfeffer 1982). Namun, beberapa penelitian terdahulu yang dilakukan Julnes dan Holzer (2001), Cavaluzzo dan Ittner (2004), Sofyani dan Akbar (2013) mengenai sistem pengukuran kinerja hanya berfokus kepada faktor internal dan eksternal organisasional yang lebih mengarah kepada hal-hal non-manusia atau individu. Sementara, Robbins dan Timothy (2010) mengemukakan bahwa kinerja atau prestasi organisasi bergantung pada kinerja individu atau anggota organisasi. Berdasarkan argumen tersebut penelitian ini menguji faktor karakteristik individu dan kai- tannya dengan implementasi sistem pengukuran kinerja di lembaga pemerintah daerah. Karakteristik yang dimaksud meliputi:tingkat self efficacy dan jenis keperibadian individu, yaitu: Conscientiousness, Opennes To Experience, dan kesesuaian kompetensi pendidikan individu dengan tugas dan peran individu tersebut di organisasi (Larson 1977; Collins 1979; DiMaggio dan Powell 1983; Gudono 2014).

Penelitian mengenai faktor karakteristik individu terhadap impelemntasi sistem penguuran kinerja penting dilakukan sebagaimana pendapat Lee dan Bobko (1994) yang mengemukakan bahwa individu yang memiliki self efficacy yang tinggi akan mencurahkan fokusnya untuk mencapai tujuan atau kinerja yang ditetapkan. Hal ini mengindikasikan bahwa Self efficacy mempunyai pengaruh terhadap hubungan antara penetapan tujuan dan kinerja individu (Robbins 1998). Sedng kan dalam hal kepribadian, McRae dan Costa (1986) dan Guadagno et al. (2007) menyatakan bahwa orang yang memiliki sifat conscientiousness secara individual mampu memecahkan masalah dan mencapai level kesuksesan yang tinggi melalui perencanaan yang penuh tujuan dan penuh ketekunan. Adapun individu yang opennes to experience cenderung imajinatif, menyukai sesuatu yang bervariasi, dan bebas. Penjelasan lain mengenai individu dengan tipe opennes to experience dikemukakan oleh McElroy et al. (2007) yang menyatakan bahwa orang dengan tipe opennes to experience memiliki keingintahuan dan kesediaan untuk mengeksplorasi suatu ide baru.

Selain tiga faktor individu di atas, Meister (1998) secara spesifik mengemukakan bahwa kompetensi merupakan pengetahuan, keterampilan, tindakan atau perilaku, dan pola pikir yang secara reliabel membedakan antara seseorang dengan orang lain khususnya dalam hal pencapaian kinerja. Dengan demikian, kompetensi dapat menggiring kepada kesuksesan dimasa mendatang (McClelland 1973). Berdasarkan kajian literatur dan beberapa penelitian terdahulu tersebut, peneliti menduga faktor karakteristik individu berupa self effi- 
cacy yang tinggi, kepribadian conscientiousnes, opennes to experience, dan kompetensi yang dimiliki pegawai pemerintah daerah, akan memberikan dampak positif terhadap implementasi sistem pengukuran kinerja.

Berbeda dengan penelitian yang dilakukan Cavaluzzo dan Ittner (2004); Julnes dan Holzer (2001); dan Sofyani dan Akbar (2013), penelitian ini tidak hanya fokus pada pengujian hipotesis yang didasarkan pada teori institusional, tetapi juga berupaya mengeksplorasi fenomena implementasi sistem pengukuran kinerja pemerintah daerah di Indonesia yang didasari pada teori isomorfisma institusional (DiMaggio dan Powell 1983). Menurut Akbar et al. (2012) studi yang mengadopsi teori institusional mengasumsikan bahwa organisasi bersaing tidak hanya untuk sumber daya dan pelanggan tetapi juga untuk kekuasaan politik dan legitimasi institusional. Oleh karena itu, dari perspektif tersebut, logika perubahan dalam sistem pengukuran kinerja (Performance Measurement SystemPMS) yang dilembagakan ke dalam organisasi akan berhubungan dengan tiga mekanisme isomorfisma: koersif, mimetik, dan normatif (Scott 1998; DiMaggio dan Powell 1983). Oleh karenanya, penelitian ini menggunakan pendekatan metoda riset campuran yang memungkinkan mampu menggali tujuantujuan penelitian yang agak kompleks.

Hasil peneleitian ini memiliki kontribusi dalam pengembangan teori isomorpisma institusional khususnya dalam kaitannya dengan upaya meningkatkan kualitas impelemtasi system pengukuran kinerja di ranah sektor publik. Selain itu hasil penelitian ini juga menjadi tambahan referensi untuk riset di bidang sektor public khususnya yang berkaitan dengan isu sistem pengukuran kinerja yang dikaitkan dengan faktor karakteristik individu.

\section{TINJAUAN PUSTAKA DAN PERUMUSAN HIPOTESIS}

\section{Isomorfisma Institutional}

Banyak literatur institusional menekankan bahwa struktur dan proses organisasi cende- rung menjadi seragam (isomorphic) dengan norma-norma yang diterima untuk jenis organisas tertentu (DiMaggio dan Powell 1983). Hal ini berakibat pada munculnya perilaku organisasi untuk melegitimasi cara-cara tertentu dalam hal pengorganisasian (Sofyani dan Akbar 2013). Dalam kajian organisasi, mayorutas studi menggunakan teori organisasi (beberapa literatur menyebutnya teori institusional) untuk menjelaskan perilaku organisasi yang diteliti (Berry et al. 2009). Namun, belakangan muncul perspektif lain yang digunakan untuk menjelaskan perilaku organisasi, khususnya sektor publik, yakni isomorfisme institusional (lihat Akbar et al. 2012; Wijaya dan Akbar 2013; Sofyani dan Akbar 2013).

Isomorfisma institusional merupakan turunan dari teori organisasi (Gudono 2014). Meyer dan Rowan (1977) dan Fennell (1980) mengemukakan ada dua jenis isomorfisma, yakni: (1) isomorfisma kompetitif (Competitive Isomorphism), yakni: asumsi rasionalitas sistem yang menekankan persaingan pasar, perubahan yang bagus, dan pengukuran kesesuaian; dan (2) isomorfisma institusional (Institutional Isomorphism); organisasi bersaing tidak hanya untuk sumber daya dan pelanggan, tetapi untuk kekuasaan legitimasi politik dan institusional, untuk kesesuaian sosial serta ekonomi. Konsep isomorfisma institusional merupakan alat yang berguna untuk memahami politik dan tata cara yang meliputi kehidupan organisasi yang lebih modern.

Isomorfisma institusional merupakan sebuah konsep yang berguna pada organisasi saat ini dimana politik dan budaya "seremonial dan adimistratif formil" tertanam dalam kehidupan organisasi, khususnya dalam organisasi sektor pubik di Indonesia (Sofyani dan Akbar 2013). DiMaggio dan Powell (1983) mengidentifikasi tiga mekanisme untuk perubahan institutional isomorphic (bagaimana organisasi menyesuaikan diri). Pertama, isomorfisma koersif (coercive), isomorfisma mimetik atau meniru-niru (mimetic), dan isomorfisma normatif (normative) yang biasanya berhubungan dengan profesionalisasi. Isomor- 
fisma koersif merupakan hasil dari tekanan formal maupun informal yang diberikan pada organisasi dengan organisasi lainnya dimana mereka saling bergantung dan didalamnya terdapat fungsi organisasi.

Isomorfisma meniru-niru terjadi ketika teknologi organisasi kurang dipahami (March dan Olsen 1976), ketika tujuan yang ambigu, atau ketika terdapat ketidakpastian lingkungan yang simbolik (Wijaya dan Akbar 2013), maka organisasi akan cenderung menjadikan diri mereka sebagai model yang sama seperti organisasi lain dan mendorong organisasi untuk melakukan imitasi. Sedangkan isomorfisma normatif berkaitan dengan profesionalisme yang ditafsirkan sebagai perjuangan kolektif dari anggota organisasi untuk menentukan kondisi dan metoda kerja mereka, untuk mengontrol "produksi" dan untuk mengembangkan kognitif dan melegitimasi otonomi pekerjaan mereka. (Larson 1977; Collins 1979; DiMaggio dan Powell 1983; Sofyani dan Akbar 2013).

Menurut Akbar et al.. (2012) studi yang mengadopsi teori institusional mengasumsikan bahwa organisasi bersaing tidak hanya untuk sumber daya dan pelanggan tetapi juga untuk kekuasaan politik dan legitimasi institusional. Oleh karena itu, dari perspektif tersebut, logika perubahan dalam sistem pengukuran kinerja (Performance Measurement System-PMS) yang dilembagakan ke dalam organisasi bisa ditempuh dengan tiga mekanisme isomorfisma institusional koersif, mimetik, dan normatif (Scott 1998; DiMaggio dan Powell 1983).

\section{Sistem Pengukuran Kinerja dan Isomorfisma}

Terbitnya Inpres No 7 tahun 1999 juga menjadi pintu gerbang reformasi birokrasi pasca orde baru. Bersamaan dengan itu lahir Sistem Akuntabilitas dan Kinerja Instansi Pemerintah (SAKIP) sebagai salah satu konsekuensi dari diterapkannya otonomi daerah di Indonesia. Namun, jika dilihat dari segi teoritis, adalah bentuk isomorfisma mimetik atau upaya meniru-niru pemerintah Indonesia terhadap pemerintahan di negara lain yang dinilai lebih maju. Menurut Tolbert dan Zucker (1983) reformasi pelayanan sipil diadopsi karena menjadi simbolis dari pemerintahan yang baik bukan karena tujuan efisiensi. Oleh karenanya, peniruan yang dilakukan dapat mengarahkan organisasi kepada pelaksanaan suatu mekanisme kerja yang hanya sebatas seremonial formal, bukan berorientasi pada substansi (March dan Olsen 1976, DiMaggio dan Powell 1983; Tolbert dan Zucker 1983; Sofyani dan Akbar 2013; Gudono 2014).

Dari pandangan lain, Sihaloho dan Halim (2005) menilai bahwa niat penggunaan sistem pengukuran kinerja lebih didominasi oleh tekanan luar (isomorfisma koersif) (Tolbert dan Zucker 1983). Hal itu dimungkinkan berdampak pada pelaksanaan sistem pengukuran kinerja yang tidak bernilai tambah tekanan yang ada hanya memunculkan kepatuhan semu atau pelaksanaan ritual yang bertujuan agar organisasi dilihat patuh oleh lingkungan di luarnya (Gudono 2014). Berangkat dari argumen di atas, kemungkinan pendorong pelaksanaan SAKIP didasari pada isomorfisme mimetic dan koersif sangat erat kaitannya dengan faktor individu atau anggota organisasi yang menjalankan organsiasi itu sendiri.

\section{Perumusan Hipotesis}

\section{Self efficacy}

Self efficacy diturunkan dari teori Kognitif sosial (Social cognitive theory) yang pertama kali dikemukakan oleh Bandura (1997). Secara sederhana teori kognitif sosial menyatakan bahwa sebagian besar pengetahuan dan perilaku anggota organisasional digerakkan dari lingkungan, dan secara terus-menerus mengalami proses berpikir terhadap informasi yang diterima. Hal tersebut memengaruhi motivasi, sikap, dan perilaku individu. Individu yang memiliki self efficacy yang tinggi akan mencurahkan semua perhatiannya untuk mencapai tujuan tertentu dari suatu tugas. Ketika menghadapi hambatan atau kesulitan dalam pencapaian tujuan, individu yang memiliki self efficacy tinggi akan berusaha secara maksimal agar mampu bertahan lebih lama dan berhasil mencapai tujuan atau kinerja yang ditetapkan (Lee dan Bobko 1994). Dengan demikian, individu yang 
memiliki self efficacy tinggi akan mungkin menjalankan sistem pengukuran kinerja sebagai suatu amanat yang harus dilakukan sebaik mungkin dan seperti yang seharusnya demi mempertahankan profesionalismenya (Larson 1977; Collins 1979). Berdasarkan uraian di atas, hipotesis yang dirumuskan adalah sebagai berikut:

H1a: Self efficacy yang tinggi dari pegawai pemerintah berhubungan positif dengan pengembangan sistem pengukuran kinerja.

H1b: Self efficacy yang tinggi dari pegawai pemerintah berhubungan positif dengan akuntabilitas kinerja.

H1c: Self efficacy yang tinggi dari pegawai pemerintah berhubungan positif dengan penggunaan informasi kinerja.

\section{Conscientiousness}

Conscientiousness (di literatur lain disebut dengan "intellect") berhubungan dengan cara individu mengontrol, mengatur, dan mengarahkan dorongan hati (impulses. Orang yang memiliki sifat conscientiousness secara individual menghindari masalah dan mencapai level kesuksesan yang tinggi melalui perencanaan yang penuh tujuan dan penuh ketekunan (McRae dan Costa 1986). Individu yang memiliki tipikal ini pada sisi positifnya sangatlah pintar dan dapat diandalkan. Dengan rasional, kedisiplinan, kehati-hatian, suka menganalisis, dapat menentukan tindakan, mengadopsi opini, dan cenderung menggunakan informasi yang tersedia untuk membuat kesimpulan atau sebagai dasar pengambilan keputusan dimiliki individu conscientiousness (Korzaan dan Boswell 2008; McRrae dan Costa 1986) mungkin untuk mengarahkan tindakan individu tersebut kepada pola perilaku normatif terhadap implementasi sistem pengukuran kinerja, khususnya di lingkup pemerintah daerah. Berdasarkan uraian di atas, maka hipotesis yang dirumuskan adalah sebagai berikut:

H2a: Conscientiousness berhubungan positif dengan pengembangan sistem pengukuran kinerja.

$\mathrm{H} 2 \mathrm{~b}$ : Conscientiousness berhubungan positif dengan akuntabilitas kinerja.
H2c: Conscientiousness berhubungan positif dengan penggunaan informasi kinerja.

\section{Opennes to Experience}

McRe dan Costa (1986) da n Guadagno et al. (2007) mengatakan bahwa individu yang memiliki opennes to experience cenderung imajinatif, menyukai sesuatu yang bervariasi, dan bebas. McElroy et al. (2007) menambahkan bahwa orang dengan tipikal opennes to experience memiliki keingintahuan dan kesediaan untuk mengeksplorasi suatu ide baru. Individu yang terbuka cenderung untuk menemukan ide-ide baru, mendapatkan nilainilai luar biasa, dan sepenuh hati mempertanyakan otoritas. Sifat imajinatif, kreatif, dan memiliki keinginan intelektual tinggi yang dimiliki individu dengan tipikal opennes to experience (Korzaan dan Boswell 2008; McRae dan Costa 1986) akan mungkin untuk mengarahkan tindakan individu tersebut kepada keinginan melaksanakan sistem pengukuran kinerja secara baik dan profesional dan tidak hanya sebatas tuntutan administratif saja. Profesionalisme adalah sumber dari munculnya isomorfisma normatif (Larson 1977; Collins 1979; DiMaggio 1983). Berdasarkan uraian di atas, maka hipotesis yang dirumuskan adalah sebagai berikut:

H3a: Opennes to experience berhubungan positif dengan pengembangan sistem pengukuran kinerja.

H3b: Opennes to experience berhubungan positif dengan akuntabilitas kinerja.

$\mathrm{H} 3 \mathrm{c}$ : Opennes to experience berhubungan positif dengan penggunaan informasi kinerja.

\section{Kompetensi Pendidikan}

Kompetensi (competency) didefinisikan sebagai karakteristik yang dimiliki seseorang yang memungkinkan mereka untuk memiliki kinerja yang unggul (McClelland 1973). Lebih jauh, McClelland (1973) menyatakan bahwa kompetensi dapat menggiring kepada kesuksesan dimasa mendatang. Sedangkan Meister (1998) secara lebih spesifik mengemukakan bahwa kompetensi merupakan pengetahuan, keterampilan, tindakan atau perilaku, dan pola pikir yang secara reliabel membedakan antara 
seseorang dengan orang lain khususnya dalam hal pencapaian kinerja. Dalam konteks penelitian ini, individu yang memiliki latar belakang pendidikan di sektor publik khususnya pemerintahan ataupun pendidikan yang sesuai dengan tugas dan jabatan yang diemban akan lebih mampu menjalankan konsep sistem pengukuran kinerja dibandingkan dengan individu yang berlatar belakang pendidikan bukan dari sektor publik dan tidak sesuai dengan tugas yang diemban. Hal ini dikarenakan konsep dari sistem pengukuran kinerja secara teoritis telah dipelajari oleh mereka yang berlatar belakang pendidikan sektor publik dan sesuai dengan tugas. Sehingga, aplikasi praktis dari konsep disiplin ilmu tersebut di lingkungan kerja menjadi lebih dipahami oleh mereka yang berlatar belakang pendidikan di sektor publik dan sesuai dengan tugasnya daripada yang tidak. Berdasarkan uraian di atas, maka hipotesis yang dirumuskan adalah sebagai berikut:

H4a: Kesesuaian tugas dengan kompetensi berhubungan positif dengan pengembangan sistem pengukuran kinerja.

H4b: Kesesuaian tugas dengan kompetensi berhubungan positif dengan akuntabilitas kinerja.

H4c: Kesesuaian tugas dengan kompetensi berhubungan positif dengan penggunaan informasi kinerja.

Sebagaimana pendapat Larson (1977) dan Collins (1979), DiMaggio (1983) isomorfisma normatif berhubungan dengan profesionalisme sebagai perjuangan kolektif dari anggota organisasi untuk menentukan kondisi dan metoda kerja mereka dan untuk mengembangkan kognitif dan melegitimasi otonomi pekerjaan mereka. Profesionalisme jarang dicapai dengan sukses karena profesional harus berkompromi dengan klien non-profesional, atasan, atau regulator. Dua aspek profesionalisasi merupakan sumber penting dari isomorfisma yakni; pertama, profesionalisasi bersandar dari pendidikan formal dan legitimasi dalam basis kognitif yang dihasilkan oleh pakar perguruan tinggi. Kedua, dihasilkan oleh pertumbuhan dan penyebaran jaringan profesional yang datang ke dalam organisasi. Dalam penelitian ini, karakteristik individu yang dimasukkan peneliti sebagai variabel independen semuanya terkait dengan dua aspek profesionalisme yang dimaksudkan di atas. Oleh karenanya, berdasarkan argumen di atas, maka peneliti membangun rumusan masalah yang akan dikaji dengan metoda kualitatif sebagai berikut:

RM: Bagaimana pemerintah daerah menjalankan sistem pengukuran kinerja dalam sudut pandang teori isomorfisma institusional? Apakah karakteristik individu yang terhubung dengan profesionalisme akan menggiring kepada isomorfisma normatif sebagaimana argumen yang dipaparkan Larson (1977), Collins (1979), DiMaggio (1983), dan Gudono (2014)?

\section{Pengembangan kinerja, akuntabilitas kinerja, dan penggunaan informasi kinerja}

Ketersediaan laporan informasi kinerja yang berorientasi hasil akan dapat meningkatkan akuntabilitas kinerja dan penggunaan informasi kinerja untuk mendukung pembuatan keputusan pada suatu organisasi (Artley dan Stroh 2001; The Urban Institute 2002). Kondisi ini menggambarkan adanya pengaruh secara langsung antara pengembangan sistem pengukuran kinerja dengan akuntabilitas kinerja dan penggunaan informasi kinerja. Kloot (1999) menyampaikan bahwa salah satu faktor yang memengaruhi peningkatan penggunaan informasi kinerja adalah informasi kinerja yang dihasilkan dari implementasi sistem pengukuran kinerja suatu organisasi. Peningkatan akuntabilitas kinerja akan meningkatkan keinginan pihak manajemen dan staf untuk menggunkan informasi kinerja dalam pembuatan keputusan. Dengan demikian terdapat pengaruh secara tidak langsung antara pengembangan sistem pengukuran kinerja terhadap penggunaan informasi kinerja melalui akuntabilitas kinerja (Cavaluzzo dan Ittner 2004; Nurkhamid 2008; Sofyani dan Akbar 2013). Berdasarkan uraian di atas, maka hipotesis yang dirumuskan adalah sebagai berikut: 
H5a: Pengembangan sistem pengukuran kinerja berhubungan langsung secara positif terhadap akuntabilitas kinerja.

H5b: Pengembangan sistem pengukuran kinerja berhubungan langsung secara positif terhadap penggunaan informasi kinerja.

H5c: Pengembangan sistem pengukuran kinerja berhubungan tidak langsung secara positif terhadap penggunaan informasi kinerja melalui akuntabilitas kinerja.

\section{METODE PENELITIAN}

Desain penelitian ini dapat dilihat pada gambar 1.

\section{Populasi, Sampel dan Level Analisis}

Penelitian dilakukan di pemerintah daerah lingkup Daerah Istimewa Yogyakarta (DIY), meliputi; Pemerintah Provinsi Daerah Istimewa Yogyakarta, Pemerintah Kabupaten Bantul, Gunung Kidul, Kulon Progo, Sleman, dan Pemerintah Kota Yogyakarta. Objek penelitian adalah Instansi Pemerintah Daerah (Dinas, Badan, dan Kantor). Metoda pemilihan sampel adalah purposive sampling, yaitu sampel dipilih berdasarkan kriteria tertentu, yakni: pejabat minimal eselon 4 (empat) di masing-masing dinas, badan, atau kantor dengan harapan para pejabat dinas/badan/kantor yang menjadi responden telah terlibat dalam proses penyusunan perencanaan strategis dan laporan kinerja sehingga responden yang dipilih diyakini telah memahami kondisi di dalam dinas, kantor atau badan yang ditempatinya (Sihaholo dan Halim 2005; Nurkhamid 2008).

\section{Teknik Pengumpulan Data}

Data yang dikumpulkan dalam penelitian ini adalah data primer melalui penyebaran angket kuesioner dan wawancara kepada responden dengan metoda penelitian campuran (mixed method). Pada beberapa kasus peneliti juga melakukan mini observasi untuk memperoleh data pendukung. Penelitian metoda campuran secara formal didefinisikan sebagai kelas penelitian yang menuntut peneliti mencampur atau menggabungkan teknik penelitian, metoda, pendekatan, konsep atau bahasa kuantitatif dan kualitatif ke dalam studi tunggal (Johnson dan Onwuegbuzie 2004).

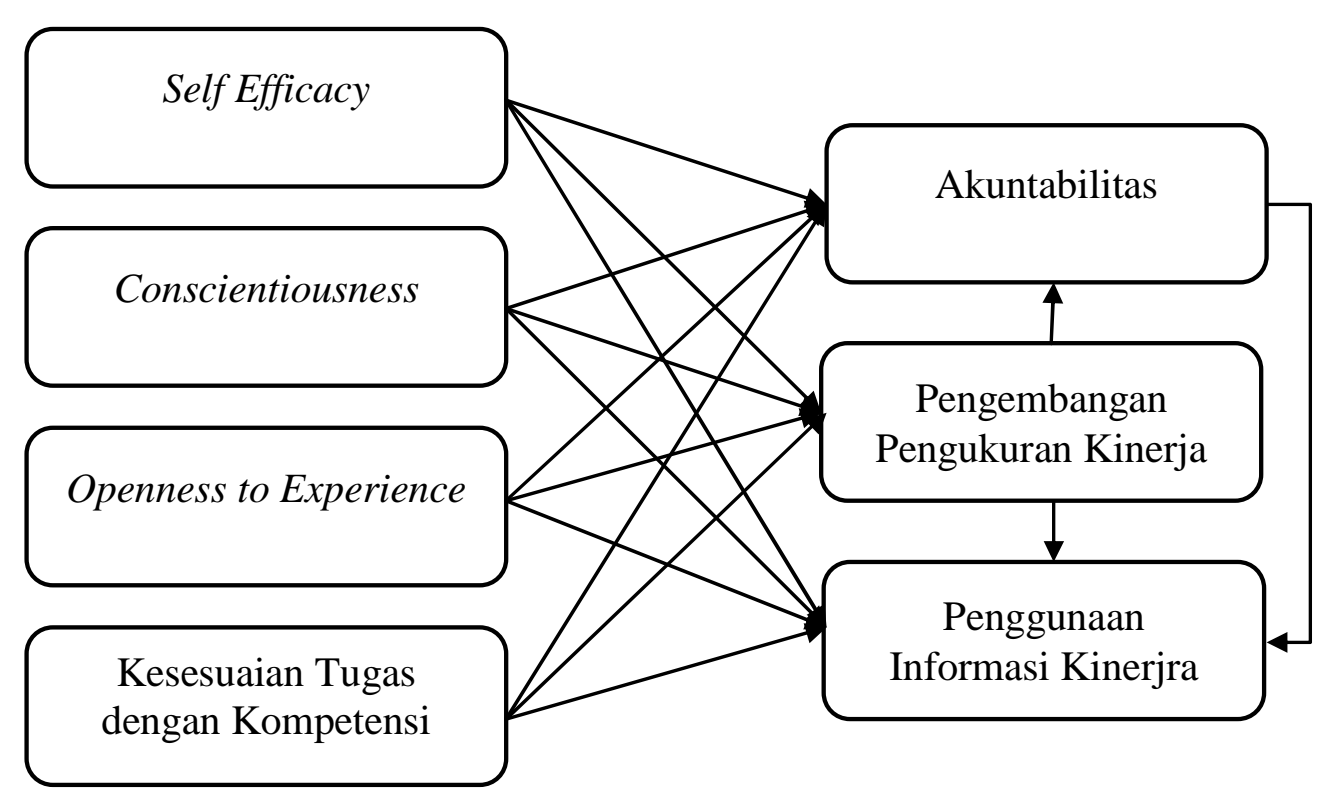

Gambar 1: Model Penelitian 


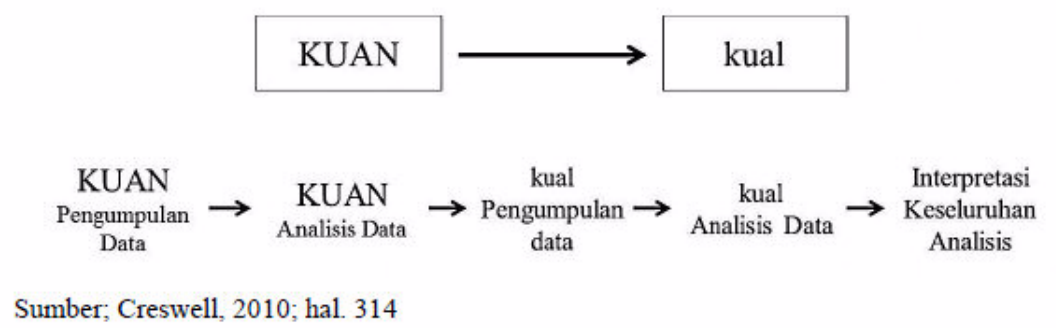

Gambar 2: Strategi Eksplanatoris Sekuensial

Strategi yang digunakan adalah eksplanatoris sekuensial (Creswell 2010), yaitu dengan pengumpulan dan analisis data kuantitatif pada tahap pertama lalu diikuti dengan pengumpulan dan analisis secara kualitatif (wawancara semi-terstruktur) pada tahap kedua yang dibangun berdasarkan hasil kuantitatif. Metoda ini digunakan karena apabila cakupan penelitian ini hanya dijelaskan dengan menggunakan data kuantitatif, maka dikhawatirkan tidak dapat menangkap fenomena isomorfisma institusional yang ingin digali. Selain itu, dengan menggunakan satu pendekatan integratif ini, peneliti mampu memperoleh pemahaman yang lebih baik serta dapat menguji hasil penelitian dari pendekatan yang berbeda (Creswell 2010).

Penggunaan metoda penelitian campuran ini bukan semata-mata karena dinilai baru, sedang naik daun, atau lagi trendi. Pendekatan metode campuran ini sangat cocok untuk penelitian ruang lingkup sektor publik karena kekhawatiran terjadinya bias normatif atau yang biasa disebut sebagai desirability bias. Oleh karenanya, penggunaan metoda penelitian campuran diharapkan mampu mendeteksi jika pada penelitian telah terjadi bias normatif tersebut, melalui mekanisme wawancara yang bisa digunakan sebagai alat konfirmasi apakah kuesioner telah diisi oleh responden sesuai keyakinannya atau tidak. Selain itu, menurut Creswell (2010) metoda penelitian campuran juga dapat digunakan untuk mengeksplorasi jika terdapat outlier dan ekstrim ketika menganalisis data kuantitatif pada tahap pertama, lalu dapat ditindaklanjuti dengan wawancara kualitatif tentang kasus-kasus outlier tersebut untuk memperoleh pengetahuan yang lebih dari hasil olah data kuantitatif.

\section{Metode Penelitian Campuran (Mixed Method Research)}

Penelitian metoda campuran terdiri dari dua jenis pendekatan penelitian, yaitu; penelitian kuantitatif yang merupakan metoda untuk menguji teori-teori tertentu dengan cara meneliti hubungan antar variabel. Sedangkan penelitian kualitatif merupakan metoda untuk mengeksplorasi dan memahami makna yang oleh sejumlah individu atau sekelompok orang dianggap berasal dari masalah sosial atau kemanusiaan. Paradigma positivistik sebagai landasan metoda kuantitatif, berurusan dengan hal-hal yang empirik (tampak) untuk dicari hubungan pada masing-masing variabelnya. Sebaliknya, paradigma interpretif sebagai landasan metoda kualitatif, berurusan dengan hal-hal yang tidak tampak untuk digali kebenaran yang sebenarnya (Creswell 2010).

Kompleksitas masalah penelitian yang dilakukan menunutut jawaban dari fenomena yang terjadi tidak hanya sekedar sederhana dalam angka-angka pada pengertian kuantitatif atau kata-kata pada penelitian kualitatif. Dengan mengkombinasikan survei dengan wawancara semi-terstruktur, maka peneliti dengan pendekatan pragmatis ini dapat membuka pintu untuk menerapkan metoda yang beragam, asumsi yang bervariasi, serta bentuk yang berbeda dalam pengumpulan data dan analisis data (Creswell 2010). Pandangan pragmatis dapat menjembatani perbedaan filosofis, yaitu mereka yang setuju dengan positivists dan post-positivists bahwa ada suatu realitas eksternal. Kedua, mereka yang menolak bahwa ada kebenaran absolut (Creswell 2010).

Menurut Hartono (2010) walaupun secara konsep penelitian metoda ilmiah 
(kuantitatif) dan naturalis (kualitatif) berbeda, tetapi sebaiknya tidak dipandang sebagai sesuatu yang bertentangan, karena keduanya memiliki kebaikan-kebaikan dan kelemahankelemahannya tersendiri, sehingga seharusnya digunakan secara komplementer, satu melengkapi yang lainnya. Pendekatan mana yang harus digunakan dalam melakukan penelitian tergantung pada tiga hal, yakni; (1) konteks penelitian, (2) kondisi atau lingkungan yang terjadi, dan (3) tingkat keluasan dan kedalaman yang diinginkan. Hartono (2010) juga menambahkan kedua pendekatan ini dapat digabungkan untuk digunakan bersama-sama. Hal ini dimungkinkan dan diharapkan dapat memberikan nilai tambah atau sinergi tersendiri karena pada hakikatnya masing-masing pendekatan mempunyai kebaikan-kebaikan sendiri. Metoda campuran dengan menghadirkan wawancara ini juga direkomendasikan oleh Nurkhamid (2008) agar penjelasan dari hasil pengujian hipotesis tidak bersifat spekulatif, tetapi benar-benar merujuk pada kondisi di lap ngan.

Keuntungan utama dari metoda penelitian campuran adalah memungkinkannya peneliti untuk secara bersamaan mengajukan pertanyaan konfirmatori dan eksplorasi dan karenanya memverifikasi dan menghasilkan teori dalam penelitian yang sama (Creswell 2010). Selain itu data wawancara yang dipakai untuk mendukung data survei memungkinkan peneliti untuk memperluas teori yang masih ada, sehingga dapat dipakai sebagai pengalaman dan pembelajaran untuk membuka perspektif baru untuk membantu mengembangkan keterampilan metodologi baru yang besar (Creswell 2010).

\section{Alat dan Teknik Analisis}

Penelitian ini akan menggunakan alat analisis Partial Least Square (PLS) untuk menguji hipotesis yang dirumuskan. Penggunaan alat analisis PLS bertujuan untuk memprediksi model dalam rangka pengembangan teori Karakteristik PLS yang bekerja dengan mengacu kepada perhitungan nilai varian dinilai sangat cocok untuk penelitian ini (Hartono dan Abdillah 2009; Sholihin dan Ratmono 2013).
Di samping itu, PLS juga kombinasi dan model yang kompleks serta dapat digunakan untuk ukuran sampel yang relatif kecil.

\section{Tahap Analisis Data}

\section{Teknik analisis data kuantitatif}

\section{Merancang Model Struktural (Inner Model)}

Model struktural digunakan untuk memprediksi hubungan kausalitas antar konstruk (variabel laten). Arah hubungan antar variabel laten dalam model penelitian ini merupakan hubungan satu arah sehingga digambarkan dengan panah arah tunggal. Terdapat dua macam konstruk dalam model, yaitu: (1) Konstruk Eksogen, merupakan konstruk yang tidak diprediksi oleh konstruk lain dalam model dan biasa disebut juga dengan variabel independen. Konstruk eksogen dapat memprediksi satu atau beberapa konstruk endogen. (2) Konstruk Endogen, merupakan konstruk yang diprediksi oleh satu atau beberapa konstruk eksogen dan hanya dapat berhubungan kausal dengan konstruk endogen dan merupakan variabel dependen.

\section{Evaluasi Model Struktural (Inner Model)}

Evaluasi model struktural dilakukan untuk menilai seberapa baik model yang diajukan untuk memprediksi konstruk yang diukur atau juga untuk mengukur tingkat variasi perubahan variabel independen terhadap variabel dependen. Evaluasi dilakukan dengan melihat skor R Square (R2) yang dihasilkan dari tabel iterasi algoritma PLS. Semakin tinggi nilai R2 (mendekati 1,00) berarti semakin baik model prediksi dari model penelitian yang diajukan.

\section{Merancang Model Pengukuran (Outer Model) dan Konstruksi Diagram Jalur}

Model pengukuran dirancang dengan cara menghubungkan indikator dengan variabel latennya. Dalam penelitian ini merupakan model indikator yang digunakan adalah jenis konstruk reflektif karena indikator-indikator pengukuran merefleksikan konstruk (variabel laten) yang dibangun. Selain itu, indikator reflektif juga sesuai untuk mengukur persepsi. Rancangan model pengukuran membentuk diagram jalur yang menunjukkan hubungan 
kausalitas antar variabel. Dalam menggambar diagram jalur (path diagram), digunakan prosedur nomogram reticular action modeling (RAM) sebagaimana ketentuan yang direkomendasikan oleh Falk dan Miller (1992), yaitu dijelaskan sebagai berikut:

a. Konstruk teoretikal yang menunjukkan suatu variabel laten digambar dengan bentuk oval atau lingkaran.

b. Variabel-variabel terukur (indikator) digambar dengan bentuk kotak.

c. Hubungan tidak simetris yang menunjukkan satu arah digambarkan dengan panah arah tunggal.

\section{Evaluasi Model Pengukuran (Outer Model)}

Model pengukuran digunakan untuk menilai validitas dan reliabilitas model. Parameter untuk menilai model pengukuran adalah validitas konvergen, validitas diskriminan yang diperoleh melalui proses iterasi algoritma.

\section{Pengujian Hipotesis}

Pengujian hipotesis untuk memprediksi adanya hubungan kausalitas diperoleh melalui uji Tstatistic yang dihasilkan dari proses bootstrap. Pengujian dilakukan dengan membandingkan nilai $\mathrm{T}$-table dengan nilai $\mathrm{T}$-statistics yang dihasilkan dari proses bootstrap. Hipotesis diterima (terdukung) jika nilai T-statistics lebih tinggi dibandingkan nilai T-table. Dengan tingkat keyakinan 95 persen (alpha 5 persen), maka nilai T-tableuntuk uji hipotesis satu ekor (one-tailed) adalah $\geq 1,64$ (Hair et al. 2006).

\section{Teknik Analisis Kualitatif}

Analisis data dilakukan dengan pendekatan analisis tematik deduktif yang menurut Braun dan Clarke (2006) merupakan metoda analitik kualitatif untuk mengidentifikasi, menganalisis dan melaporkan pola atau tema yang terdapat didalam data. Analisis tematik sendiri merupakan salah satu klasifikasi dari teknik analisis isi (content analysis). Langkah-langkah yang ditempuh meliputi melakukan coding, mengelompokkan dalam kategorikategori, menemukan ide utama dan mengelompokkannya ke dalam tema-tema, selanjutnya menemukan pola umum dari kecende- rungan yang berhasil ditemukan dari data. Dalam analisis tematik peneliti tidak diperlukan penjelasan rinci tentang kerangka teori dan pendekatan yang digunakan, akan tetapi untuk membuat menjadi jelas posisi teori tertentu menjadi penting untuk disandarkan (Braun dan Clarke 2006). Dalam proses analisis dan penentuan tema, peneliti menggunakan konsep teori isomorfisma institusional yang berhubungan dengan masalah yang sedang dikaji untuk membantu menjelaskan hasil berdasarkan temuan data di lapangan.

Untuk memastikan realibilitas dan validitas dari data kualitatif yang sudah terkumpul, maka bisa melakukan beberapa prosedur, antara lain; untuk memastikan validitas data dengan memeriksa kembali hasil transkrip untuk memastikan tidak adanya kesalahan yang dibuat selama proses transkripsi. Lalu untuk memastikan reliabilitas data, maka perlu melakukan tanya-jawab dengan sesama rekan peneliti (peer de-briefing) untuk meningkatkan keakuratan hasil penelitian (Creswell 2010).

\section{Difinisi operasional dan pengukuran variabel}

\section{Self Efficacy}

Variabel ini menggambarkan tingkat keyakinan responden terhadap kemampuannya dalam melaksanakan tugas dan mencapai target kinerja yang telah ditetapkan. Instrumen yang digunakan untuk mengukur variabel ini diadopsi dari Bandura (1997) dengan menggunakan skala likert 1-5 $(1=$ sangat tidak setuju sampai dengan $5=$ sangat setuju).

\section{Conscientiousness}

Variabel ini menggambarkan karakter responden seperti rasional, suka menganalisis, dapat menentukan tindakan, dan mengadopsi opini, dan cenderung menggunakan informasi yang tersedia untuk membuat kesimpulan atau sebagai dasar pengambilan keputusan (Korzaan dan Boswell 2008). Instrumen yang digunakan untuk mengukur variabel ini diadopsi dari Korzaan dan Boswell (2008) berdasarkan International Personality Item Pool (IPIP) dengan menggunakan skala likert 1-5 (1 $=$ sangat tidak setuju sampai dengan $5=$ sangat setuju). 


\section{Opennes To Experience}

Variabel ini menggambarkan karakter responden seperti rasa keingintahuan intelektual. Orang yang tingkat Opennes To Experiencenya tinggi cenderung lebih mudah menerima dan memiliki banyak toleransi terhadap halhal atau ide baru, serta memiliki keinginan dan kemauan untuk mengalami hal baru atau merumuskan ide baru (Korzaan dan Boswell 2008). Instrumen yang digunakan untuk mengukur variabel ini diadopsi dari Korzaan dan Boswell (2008) berdasarkan International Personality Item Pool (IPIP) dengan menggunakan skala likert $1-5(1=$ sangat tidak setuju sampai dengan $5=$ sangat setuju).

\section{Keseusaian Tugas dengan Kompetensi Pen- didikan}

Variabel ini menggambarkan kesesuaian tugas dan jabatan individu dengan kompetensi akademik individu tersebut. Variabel ini diukur dengan melihat program studi responden sewaktu menempuh pendidikan tinggi dengan tugas dan jabatan yang diemban responden saat ini.

\section{Pengembangan Sistem Pengukuran Kinerja}

Variabel ini menunjukkan upaya organisasi melakukan pengembangan sistem pengukuran kinerja yang dicerminkan dengan penentuan dan penetapan berbagai tipe ukuran kinerja yang berorientasi hasil untuk berbagai kebijakan/program/kegiatan yang dijalankan oleh suatu organisasi. Instrumen yang digunakan untuk mengukur variabel ini diadopsi dari Cavaluzzo dan Ittner (2004) dengan menggunakan skala Likert 1-5 (1 = sangat tidak setuju sampai dengan $5=$ sangat setuju).

\section{Akuntabilitas Kinerja}

Variabel ini mengukur sejauh mana para manajer merasa bertanggungjawab untuk mencapai target capaian dari suatu program/kegiatan/kebijakan yang dijalankan oleh organisasi. Instrumen yang digunakan untuk mengukur variabel ini diadopsi dari Cavaluzzo dan Ittner (2004) dengan menggunakan skala Likert 1-5 (1 = sangat tidak setuju sampai dengan $5=$ sangat setuju).

\section{Penggunaan Informasi Kinerja}

Variabel ini mengungkapkan berbagai jenis penggunaan informasi kinerja untuk mendukung pengambilan keputusan dalam suatu organisasi. Instrumen yang digunakan untuk mengukur variabel ini diadopsi dari Cavaluzzo dan Ittner (2004) dengan menggunakan skala Likert 1-5 (1 = sangat tidak setuju sampai dengan $5=$ sangat setuju).

\section{HASIL PENELITIAN DAN PEMBAHASAN}

\section{Pilot Test}

Sebelum instrumen penelitian disebarkan kepada para responden, instrument harus diuji terlbeih dahulu validitas dan reliabilitasnya. Untuk itu, instrumen kuesioner terlebih dahulu diujicobakan (pilot test) kepada responden yang memiliki karakteristik sama dengan calon sampel penelitian. Pilot test dilakukan kepada para pegawai pemda yang sedang menempuh kuliah di Magister Ekonomi Pembangunan Universitas Gadjah Mada Yogyakarta (MEP UGM). Dari hasil penyebaran 50 instrumen diperoleh 31 instrumen yang layak untuk diujikan dan selanjutnya dianalisis dengan menggunakan software SmartPLS. Hasil pilot study menunjukkan bahwa nilai AVE dan Сотmunality masing-masing $>0,5$ dan mendekati 0,5 . Nilai Composite Reliability masing-masing $>0,6$ dan cross loading > 0,6. Selain itu, pada hasil cross loading dapat ditemukan masingmasing indikator yang ada pada suatu variabel laten (konstruk) mempunyai nilai cross loading tertinggi pada konstruk yang dituju dibandingkan dengan nilai yang ada pada konstruk lainnya. Hasil tersebut menunjukkan bahwa pertanyaan-pertanyaan dalam penelitian ini valid dan reliabel, sehingga layak digunakan untuk penelitian (Chin 1998).

\section{Gambaran Umum Responden}

Pengumpulan data dilakukan dua tahap dengan metoda berbeda, yakni, pertama: pengumpulan data kuantitatif dengan menyerahkan kuesioner penelitian pada masing-masing Satuan Kerja Perangkat Daerah (SKPD) di wilayah Pemerintah Provinsi DIY. Kemudian, hasil jawaban 
kuesioner dirangkum dan dianalisis dengan software SmartPLS. Tahap kedua: hasil olah data kuantitatif digunakan sebagai dasar melakukan perumusan pertanyaan yang akan diajukan dalam wawancara terhadap responden yang tersebar di enam daerah penelitian. Adapun rincian response rate dan usable response rate dapat disimak pada Tabel 1.

\section{Analisis Data Kuantitatif}

\section{Non-Response Bias}

Pengumpulan data dilakukan dalam dua periode yang berbeda, yakni minggu pertama dan kedua. Untuk memastikan tidak ada perbedaan jawaban responden dari dua periode tersebut, maka 60 respon akhir (tujuh hari kerja kedua) dibandingkan dengan tanggapan sebelumnya yaitu 59 respon awal (tujuh hari kerja pertama) menggunakan Mann-Whitney Test (Field 2009). Dari hasil Mann-Whitney Test dapat disimpulkan bahwa tidak terdapat per- bedaan signifikan dari semua variabel yang digunakan [Asymp. Sig. (2-tailed)] > 0.05.

Selain itu, dengan daerah penelitian yang cukup luas, yakni meliputi enam wilayah, maka untuk memastikan tidak ada perbedaan jawaban responden antar wilayah, dilakukan Kruskal Wallis Test, yakni uji nonparametrik yang digunakan untuk membandingkan tiga atau lebih kelompok data sampel secara bersamaan (Supangat 2007). Dari hasil Kruskal Wallis Test ditemukan nilai Asymp. Sig. > 0.05 yang artinya tidak terdapat perbedaan jawaban dari responden di enam wilayah berbeda yang dijadikan sampel penelitian.

\section{Hasil Perancangan Model Struktural}

Dalam model struktural ini, terdapat 14 konstruk yang terdiri dari 11 konstruk eksogen (independen) dan 3 (tiga) konstruk endogen (dependen). Model struktural ditunjukkan pada gambar 1 .

Tabel 1: Rincian Respon Rate dan Usebale Respon rate

\begin{tabular}{lcccccc}
\hline Keterangan & Disebar & Diterima & $\begin{array}{c}\text { Tidak } \\
\text { Lengkap }\end{array}$ & $\begin{array}{c}\text { Tidak Sesuai } \\
\text { Kriteria sampel }\end{array}$ & Dianalisis & $\begin{array}{c}\text { \% Dari Jlh } \\
\text { Disebar }\end{array}$ \\
\hline DIY & 24 & 22 & 6 & 2 & 14 & $58,33 \%$ \\
Yogyakarta & 21 & 19 & 3 & 1 & 15 & $71,43 \%$ \\
Sleman & 24 & 21 & 7 & 3 & 11 & $45,83 \%$ \\
Bantul & 29 & 27 & 2 & 2 & 23 & $79,31 \%$ \\
Gunung Kidul & 23 & 23 & 5 & 4 & 14 & $60,87 \%$ \\
Kulon Progo & 21 & 21 & 1 & 0 & 20 & $95,24 \%$ \\
Jumlah & $\mathbf{1 4 2}$ & $\mathbf{1 3 3}$ & $\mathbf{2 4}$ & $\mathbf{1 2}$ & $\mathbf{9 7}$ & $\mathbf{6 8 , 3 1 \%}$ \\
\hline
\end{tabular}

Tabel 2: Ringkasan Iterasi Algoritma PLS

\begin{tabular}{lcccc}
\hline Var & $\boldsymbol{A V E}$ & Composite Reliability & Cronbachs Alpha & Communality \\
\hline AKT & 0,47387 & 0,777464 & 0,613566 & 0,47387 \\
CON & 0,67316 & 0,89147 & 0,839625 & 0,67316 \\
KTDK & 1 & 1 & 1 & 1 \\
OTE & 0,710309 & 0,907303 & 0,870019 & 0,710309 \\
PIK & 0,665424 & 0,908587 & 0,874145 & 0,665424 \\
PSPK & 0,645509 & 0,878533 & 0,81845 & 0,645509 \\
SE & 0,538317 & 0,821524 & 0,747657 & 0,538317 \\
\hline R Square & & & & \\
AKT & & & & 0,473236 \\
PIK & & & & 0,50844 \\
PSPK & & & 0,286024 \\
\hline
\end{tabular}

Catatan: nilai R Square: 0,67 = substantial, $0,33=$ moderate, $0,19=$ weak, $($ Chin 1998; Chin et al. 2003; Henseler 2009) 


\section{Evaluasi Model Pengukuran}

\section{Uji Validitas Konvergen}

Parameter uji validitas konvergen dilihat dari skor AVE dan communality. Skor masingmasing variabel, kecuali AKT (Akuntabilitas) bernilai di atas 0,5 . Artinya, probabilitas indikator di suatu konstruk masuk ke variabel lain lebih rendah (kurang 0,5). Sehingga, probabilitas indikator tersebut konvergen dan masuk di konstruk yang dimaksud lebih besar, yaitu di atas 0,5 atau $50 \%$. Meskipun idealnya skor AVE >0,5, namun skor >0,4 masih diberi toleransi (Lai dan Fan, 2008; Vinzi et al., 2010).

\section{Uji Validitas Diskriminan}

Parameter validitas diskriminan mengacu pada skor cross loading. Dari hasil pengujian Cross Loading ditemukan masing-masing indikator di suatu konstruk di dalam model pengukuran telah memenuhi syarat validitas diskriminan karena masing-masing indikator di suatu konstruk berbeda dengan indikator di konstruk lain dan mengumpul pada konstruk yang dimaksud dengan skor $>0,6$.

\section{Uji Reliabilitas}

Uji reliabilitas dapat dilihat dari skor Composite Reliability dan Crombach Alpha dengan syarat nilainya > 0,6 (Hair et al. 2006; Hartono dan Abdillah 2009). Dari Tabel 2 da- pat disimak skor Composite Reliability semua konstruk lebih dari 0,6. Begitu pula untuk skor Crombach Alpha, semua konstruk juga memiliki skor lebih dari 0,6. Dengan demikian, konstruk-konstruk penelitian dinyatakan reliabel dan layak digunakan untuk pengujian hipotesis.

\section{Evaluasi Model Struktural}

Model struktural dievaluasi dengan menggunakan $\mathrm{R}^{2}$ (R-Square) untuk konstruk dependen. Dari Tabel 2 dapat disimak bahwa nilai $\mathrm{R}^{2}$ untuk konstruk AKT (Akuntabilitas) adalah sebesar 47,32\%, nilai $\mathrm{R}^{2}$ untuk konstruk PIK (Penggunaan Informasi Kinerja) adalah sebesar 50,84\% persen dan nilai $\mathrm{R}^{2}$ untuk konstruk PSPK (Pengembangan Sistem Pengukuran Kinerja) adalah sebesar $28,60 \%$. Nilai-nilai tersebut bermakna bahwa model penelitian yang diajukan dapat menjelaskan variabel konstruk AKT (Akuntabilitas) sebesar 47,32\%, konstruk PIK (Penggunaan Infromasi Kinerja) sebesar 50,84\%, dan konstruk PSPK (Pengembangan Sistem Pengukuran Kinerja) sebesar $28,60 \%$,. Sedangkan sisanya dijelaskan oleh variabel lain di luar model yang diajukan.

\section{Hasil Pengujian Hipotesis}

Ringkasan hasil pengujian hipotesis disajikan pada Tabel 3.

Tabel 3: Ringkasan Hasil Pengujian Hipotesis

\begin{tabular}{cccccc}
\hline Hipotesis & Hubungan & Arah & Koefesien & Nilai-T & Hasil \\
\hline H1a & SE $\rightarrow$ AKT & + & 0,083529 & 0,732224 & Tidak Terdukung \\
H1b & SE $\rightarrow$ PIK & + & 0,145 & 1,297199 & Tidak Terdukung \\
H1c & SE $\rightarrow$ PSPK & + & 0,209785 & $1,733182^{*}$ & Terdukung \\
H2a & CON $\rightarrow$ AKT & + & 0,15637 & 1,270705 & Tidak Terdukung \\
H2b & CON $\rightarrow$ PIK & + & 0,175011 & $1,797711^{*}$ & Terdukung \\
H2c & CON $\rightarrow$ PSPK & + & 0,01212 & 0,08046 & Tidak Terdukung \\
H3a & OTE $\rightarrow$ AKT & + & 0,06031 & 0,599775 & Tidak Terdukung \\
H3b & OTE $\rightarrow$ PIK & + & 0,012862 & 0,117262 & Tidak Terdukung \\
H3c & OTE $\rightarrow$ PSPK & + & 0,035696 & 0,328744 & Tidak Terdukung \\
H4a & KTDK $\rightarrow$ AKT & + & 0,04521 & 0,581382 & Tidak Terdukung \\
H4b & KTDK $\rightarrow$ PIK & + & $-0,07485$ & 0,959456 & Tidak Terdukung \\
H4c & KTDK $\rightarrow$ PSPK & + & $-0,01049$ & 0,137729 & Tidak Terdukung \\
H5a & PSPK $\rightarrow$ AKT & + & 0,239338 & $2,727981 *$ & Terdukung \\
H5b & PSPK $\rightarrow$ PIK & + & 0,267782 & $2,465997 *$ & Terdukung \\
H5c & PSPK $\rightarrow$ AKT $\rightarrow$ PIK & + & 0,481327 & $5,575069 *$ & Terdukung \\
\hline
\end{tabular}

Catatan: *signifikan pada nilai T-Table 1,64 (one-tailed) dan P-value <0,05 


\section{Analisis Data Kualitatif}

Dari hasil pengujian hipotesis, variabel self efficacy dan conscientiousness secara empirik berhubungan positif terhadap implementasi sistem pengukuran kinerja, masing-masing dalam hal pengembangan sistem pengukuran kinerja dan penggunaan informasi kinerja. Menurut beberapa responden, keberhasilan pelaksanaan sistem pengukuran kinerja dan pencapaian kinerja dinilai akan bisa diraih oleh adanya ketekunan, dedikasi, dan kematangan intelektual pegawai pemda. Beberapa karakter tersebut berperan penting dalam meningkatkan profesionalitas kerja yang mampu melahirkan isomorfisma normatif. Hasill ini sejalan dengan pendapat Lee dan Bobko (1994) dan Guadagno et al. (2007). Hasil ini juga sejalan dengan paparan beberapa responden yang diperoleh dari hasil wawancara.

"....komitmen penting dimiliki pegawai. Setelah itu dedikasi dan loyalitas kepada atasan..."1 (Kepala Seksi Perencanaan dan Evaluasi Dinas Pendidikan Dasar Bantul)

"Orang yang tekun dan dia bisa bertahan dengan rutinitas yang mampu memberikan kinerja baik..." (Kasubbid Litbang Sarpras dan Tata Ruang Bappeda Kota Yogyakarta)

“...bekerja dengan jiwa itu bisa dilakukan jika bekerja karena kesesuaian antara kemampuan dan modal ilmu yang dimiliki dengan tugas yang dikerjakan. Sehingga, ketika orang itu tepat di bidangnya biasanya mereka lebih kompeten, lebih tekun, lebih menjiwai, lebih kreatif juga."(Kasubbag Perencanaan Dinas Parpora Kulon Progo)

“...ya harus punya intelektual, semangat tinggi, tekun, loyal, dan mudah beradaptasi..." (Analis Kebutuhan Program Diklat Badan Kepegawaian Daerah DIY)

Sedangkan variabel opennes to experience yang identik dengan karakter seseorang yang kreatif secara statistik tidak berhubungan signifikan dengan pelaksanaan sistem pengukuran kinerja. Tidak terdukungnya variabel opennes to experience bisa jadi dikarenakan pada realita di lapangan yang ditemukan peneliti, yakni tugas dan wewenang pegawai pemda dibatasi oleh peraturan. Sehingga, kapasitas pegawai pemda untuk melakukan improvosasi atau kreatifitas dalam hal tertentu tidak dapat dilakukan. Hal ini sejalan dengan yang disampaikan beberapa responden berikut:

"Kami membutuhkan orang tekun, tapi juga penuh kreatifitas. Kalau orang tekun tapi tidak kreatif nanti saklek... Tapi kita melayani masyarakat dan kita menegakkan kebijakan bupati dengan berbagai kebijakannya harus sesuai dengan perda yang ada. Kita (satpol $\mathrm{PP}$, pen) sebagai kepanjangan tangan pimpinan, maka pelaksanaan operasi di lapangan tetap harus sesuai peraturan." (Kepala Kantor TU Satpol PP Gunung Kidul)

Berikut beberapa pendapat dari responden lain yang serupa dengan pendapat dari responden Gunung Kidul di atas:

“... ruang gerak kita dibatasi... Kan sudah ada plotnya. Jadi kita tinggal mengisi. Jadi memang daya ekspresi kita tidak tertuangkan di sini. Jadi analisisnya ya apa adanya." (Kepala Seksi Perencanaan dan Evaluasi Dinas Pendidikan Dasar Bantul)

"Orang kreatif tidak punya ruang disini. Idealnya posisi litbang itu adalah fungsional peneliti. Jadi dia langsung betanggungjawab ke kepala bappeda... Saya pikir birokrasi kita memang belum memberikan ruang kepada insan kreatif..."2 (Kasubbid Litbang Sarpras dan Tata Ruang Bappeda Kota Yogyakarta)

“...ketika orang itu tepat di bidangnya biasanya mereka lebih kompeten, lebih tekun, lebih menjiwai, lebih kreatif juga. Contohnya saat acara seni, mereka alumni Institut Seni Indonesia itu 
bekerja cepat dan bagus. Tapi kalau yang lain mengerjakan tentu tidak sebagus orang seni.”(Kasubbag Perencanaan Dinas Parpora Kulon Progo)

\section{Kesesuaian Tugas dengan Kompetensi Pendidikan}

Dari hasil pengujian hipotesis, variabel kesesuaian tugas dengan kompetensi pendidikan secara empirik tidak berhubungan terhadap implementasi sistem pengukuran kinerja, baik dalam hal pengembangan sistem pengukuran kinerja, pelaporan akuntabilitas kinerja maupun penggunaan informasi kinerja. Keadaan ini bisa jadi dikarenakan ketidaksesuaian tugas dengan kompetensi pendidikan dapat ditutupi oleh adanya pelatihan, kompetensi non-akademik yang dimiliki pegawai (seperti: kemampuan mengontrol emosi, kemampuan memimpin, kemampuan menyesuaikan diri dan mengembangkan kapasitas kompetensi dan intelektual, dsb), dan pengalaman pegawai $\mathrm{SKPD}^{3}$. Pengalaman di dianggap mampu menjadi modal untuk menyesuaikan diri di instansi baru jika terjadi rolling jabatan atau tempat kerja.

Di samping itu, adanya tuntutan untuk siap ditempatkan di posisi manapun juga berkemungkinan menjadi alasan lain. Fakta di lapangan yang ditemukan adalah kesesuaian antara formasi (posisi/tugas) dengan kompetensi pegawai pemda sangat sulit dicapai karena adanya kesenjangan yang cukup tinggi antara formasi jenis pekerjaan dengan spesifikasi pegawai yang tersedia saat rekrumen pegawai pemerinth daerah dilaksanakan. Hal ini sejalan dengan apa yang disampaiakan oleh responden dari Sleman dan Bantul berikut ini:

"Saya rasa ketika pejabat atas seperti orang di Badan Kepegawaian Daerah (BKD) berkoordinasi dengan kepalakepala SKPD untuk mendiskusikan penempatan pegawai, mereka tentu mempertimbangkan segala hal terkait siapa yang akan menempati posisi tertentu. Entah itu kompetensi, kemampuan lain, pengalaman, ataupun faktor lain semuanya dipertimbangkan. Jadi menurut saya, spesifikasi dalam hal kompetensi tidak begitu berpengaruh dalam pelaksanaan sistem pengukuran kinerja dan dalam hal pencapaian kinerja. Disamping itu juga ada pelatihan yang dapat memberi kontribusi positif dari yang tadinya antara kompetensi dengan pekerjaannya tidak sesuai menjadi sesuai dan mampu bekerja di posisi yang diembannya." (Kepala Seksi Perencanaan dan Evaluasi Dinas Pendidikan Dasar Bantul)

"Tidak harus sesuai. Tapi, tidak boleh keluar dari rumpun. Misalnya di kepala kantor perpus ya idealnya dari IPS (Ilmu Pengetahuan Sosial). Misalnya insinyur jadi kepala perpus kan tidak pas. Artinya tidak harus sesuai tapi tidak boleh keluar dari rumpun. Kan ketidaksesuaian itu bisa dikembangkan dengan pelatihan dan juga pengalaman yang bersangkutan..." (Kepala Kantor Perpusda Sleman)

Meski demikian, terdapat pula argumen berbeda dari beberapa responden lain yang menyatakan bahwa ketidaksesuaian tugas dan kompetensi adalah masalah besar dan mengganggu impelementasi sistem pengukuran kinerja, khususnya dalam upaya pencapaian kinerja. Berikut beberapa pendapat responden yang kontra dengan pendapat dari responden dari Bantul dan Sleman:

"...ya memang jika the right man in the right position tentu berbeda dengan wrong man in the wrong position. Saya mencontohkan spesifik saja... Kalau di bagian kebudayaan kan banyak alumni ISI (Institut Seni Indonesia), itu memang sangat cocok sekali. Mereka intuisinya sangat kuat ketimbang kami yang non lulusan seni, kalau kami tune nya kurang..." (Kasubbag Perencanaan Dinas Parpora Kulon Progo).

"Lha ini (dengan terkejut dan antusias mendengar pertanyaan peneliti)... Saya pikir kita semua sudah tahu yang namanya the right man in the right place. Seseorang kalau ingin melak- 
sanakan tugas maksimal dan ingin hasil maksimal pula, maka SKPD khususnya BKD harus menempatkan seseorang sesuai dengan keahlian dibidangnya. Namun kita melihat selama ini, kadang-kadang karena berbagai kebijakan, ada hal yang kurang pas, maka kita berusaha untuk menyesuaiakan. Saya berharap agar dalam mengisi kekosongan pejabat yang ada, diambilkan dari orang yang membidangi kaitannya dengan penegakaan perda atau hukum, itu dari sajana hukum. Kami harap jangan ditempatkan orang yang asal (tidak sesuai, pen), hanya karena orang tersebut golongannya sudah mencukupi lalu ditempatkan diposisi itu. Jadi, kalau bisa ya harus the right man in the right place. Kalau di Pol PP ada pendidikan dasar ke Pol PP-an untuk penyesuaian kompetensi dengan tugas di Satpol PP. Ini semacam matrikulasi kalau di perguruan tinggi."'(Kepala Kantor TU Satpol PP Gunung Kidul).

"Oya, itu masalah besar. Saya alami sendiri. Jadi saya masuk bappeda dulu di bagian sekretariat. Saya pernah pengalaman menbuat LAKIP. Basic saya teknik arsitektur, magister urban management dan urban planning, tapi jadi kepala TU waktu itu. Itu nggak banget (tidak sesuai dengan spesifikasi kompetensi, pen). Cuma problem-nya memang pada tingkat struktural itu sering dirotasi. Problem-nya lagi adalah SDM yang dipunya dengan formasi yang tersedia itu tidak selalu match. Sehingga, memang ada beberapa formasi yang akhirnya tidak matching dengan profile orang yang mengisi itu (formasi, pen). Ini problem, dan pelatihan tidak bisa mengatasi masalah itu. Saya orang teknik biasanya lemah di administrasi tapi disuruh membawahi bidang administrasi. Saya pikir birokrasi kita yang di indonesia ini hanya mengikuti trend, jadi hanya sebatas labeling, belum masuk ke level esensi." (Kasubbid Litbang Sarpras dan Tata Ruang Bappeda Kota Yogyakarta).

"ya masalahnya kan karena seringkali kita (satuan kerja perangkat daerah, pen) dimasuki oleh "orang-orang titipan"... entah dari mana datangnya (orang titipan)... masalah berikutnya adalah "orang-orang titipan" ini seringkali tidak memiliki komepetensi bahkan hasil kerjanya jelek... yaaa... memang mau tidak mau kita menghadapi realita politik seperti ini... dan orang di pemda sudah maklum dengan keaadan seperti ini... sangat disayangkan..."5 (Kasubbag dinas perhubungan Bantul).

Dari pendapat responden Kota Yogyakarta, Kulon Progo, Gunung Kidul, dan Bantul di atas ditemukan adanya indikasi bahwa banyak dari pegawai pemda menginginkan kondisi yang ideal, yakni formasi yang disesuaikan dengan kompetensi pendidikan. Ketidaksesuaian dianggap sebagai kendala dan masalah yang menghambat pelaksanaan sistem pengukuran kinerja yang selanjutnya berpengaruh terhadap pencapaian kinerja. Responden dari Bappeda kota Yogyakarta bahkan menilai bahwa fenomena ketidaksesuaian antara tugas dan jabatan mengindikasikan bahwa pelaksanaan sistem pengukuran kinerja di Indonesia hanya upaya legitimasi dan "labeling" yang dalam sudut pandangan isomorfisma institusional disebut dengan isomorfisma mimetik. Situasi ini juga mengindikasikan bahwa pelaksanaan system pengukuran kinerja di SKPD belum menyentuh level esensi atau isomorfisma yang sifatnya normatif. Namun, karena kondisi yang ada sulit untuk ideal, maka setiap SKPD melakukan penyesuaian diri dengan cara berbeda.

Kondisi ketidaksesuaian tugas dan kompetensi tersebut selanjutnya memicu fenomena isomorfisma koersif sebagaimana yang terjadi di Bappeda pemkot Yogyakarta dan mungkin juga terjadi di banyak SKPD di lingkup pemda DIY dimana pegawai pemda dituntut untuk melaksanakan tugas yang telah 
diemban kepadanya, khususnya dalam pelaksanaan system pengukuran kinerja. Selain itu, fenomena tersebut juga memicu isomorfisma normatif sebagaimana yang terjadi di Satpol PP Gunung Kidul sebagai respon menyikapi kondisi tidak idealnya posisi dengan kompetensi pendidikan khususnya terkait pelaksanaan sistem pengukuran kinerja dengan membuat program pelatihan khusus kesatpol PP-an untuk membantu pelaksanaan tugas pegawai.

Responden dari Disparpora Kulon Progo mengemukakan kesesuaian tugas dengan kompetensi pendidikan sudah menjadi pertimbangan penting oleh Badan Kepegawaian Daerah Kulon Progo dan kepala SKPD, meskipun dalam realita di lapangan kondisi ideal ini masih sangat sulit diwujudkan. Pada kondisi tugas sesuai dengan kompetensi, hal itu akan sangat membantu impelementasi sistem pengukuran kinerja, baik dalam pengembangan sistem pengukuran kinerja maupun upaya pencapaian kinerja dan akuntabilitas kinerja. Kesusaian tugas dan kompetensi pendidikan ini memicu dorongan pelaksanaan sistem pengukuran kinerja dari fenomena isomorfismanormatif.

Di sisi lain, ketika responden dari BKD DIY dikonfirmasi mengenai pertimbangan apa yang menjadi dasar BKD menempatkan seorang pegawai pada posisi yang tidak sesuai dengan kompetensinya, responden hanya menjawab "tidak tahu", seagaimana yang dikutip berikut ini:

"Kalau itu saya kurang tahu karena itu kebijakan pimpinan langsung."(Analis Kebutuhan Program Diklat Badan Kepegawaian Daerah DIY)

Namun, dari jawaban responden dari BKD DIY tersebut, dapat ditemui adanya opini yang sejalan dengan yang dipaparkan oleh Kasubbag dinas perhubungan Bantul, bahwa tidak sesuainya tugas dan kompetensi dipengaruhi oleh kebijakn yang bersifat politis dan sudah menjadi hal yang dimaklumi di lingkungan pemda.

\section{SIMPULAN}

Penelitian ini merupakan perpaduan dari analisis kuantitatif dan kualitatif, sehingga kele- bihannya adalah peneliti dapat menemukan informasi yang lebih mendalam mengenai masalah penelitian yang ingin diuji. Variabel self efficacy dan conscientiousness secara empirik dengan pendekatan kuantitatif berhubungan positif terhadap implementasi sistem pengukuran kinerja. Hasil ini sejalan dengan pendapat Lee dan Bobko (1994) dan Guadagno et al. (2007) sebagaimana yang dipaparkan dalam perumusan hipotesis. Tetapi hubungan yang tercipta dari masing-masing variabel hanya dalam hal pengembangan sistem pengukuran kinerja dan penggunaan informasi kinerja. Pada kasus ini, self efficacy dan conscientiousness mampu memicu terjadinya isomorfismanormatif.

Dari hasil pengujian hipotesis, kesesuaian tugas dengan kompetensi pendidikan secara empirik tidak berhubungan terhadap implementasi sistem pengukuran kinerja, baik dalam hal pengembangan sistem pengukuran kinerja, pelaporan akuntabilitas kinerja maupun penggunaan informasi kinerja. Dari hasil analisis kualitatif, dijelaskan bahwa keadaan ini bisa jadi dikarenakan ketidaksesuaian tugas dengan kompetensi pendidikan dapat ditutupi oleh adanya pelatihan, kompetensi non-akademik yang dimiliki pegawai (seperti: kemampuan mengontrol emosi, kemampuan memimpin, kemampuan menyesuaikan diri dan mengembangkan kapasitas kompetensi dan intelektual, dsb), dan pengalaman pegawai SKPD.

Pengalaman dianggap mampu menjadi modal untuk menyesuaikan diri di instansi baru jika terjadi rolling jabatan. Kondisi ini adalah ciri dari isomorfisma mimetik. Di samping itu, adanya tuntutan (koersif) untuk siap ditempatkan di posisi manapun juga berkemungkinan menjadi alasan lain. Faktanya di lapangan, memang kesesuaian antara formasi (posisi/tugas) dengan kompetensi pegawai pemda sangat sulit dicapai karena adanya kesenjangan yang cukup tinggi antara formasi dengan spesifikasi pegawai yang tersedia. Meski demikian, dari hasil analisis kualitatif pula diperoleh argumen berbeda yang menyatakan bahwa ketidaksesuaian tugas dan kompetensi adalah masalah besar dan mengganggu 
impelementasi sistem pengukuran kinerja, khususnya dalam upaya pencapaian kinerja. Pada kondisi tugas sesuai dengan kompetensi, hal itu akan sangat membantu impelementasi sistem pengukuran kinerja, baik dalam pengembangan sistem pengukuran kinerja maupun upaya pencapaian kinerja dan akuntabilitas kinerja. Berdasarkan penjelasan tersebut, dapat disimpulkan bahwa dorongan yang mucul pada pelaksanaan sistem pengukuran kinerja adalah dari isomorfisma koersif dan mimetik jika terjadi ketidaksesuaian, dan dari isomorfisma normatif jika kesesuaian tugas dan kompetensi pendidikan itu terpenuhi.

Implikasi penting dari hasil penelitian ini adalah bahwa untuk menunjang keberhasilan implementasi sistem pengukuran kinerja, karakter individu pegawai pemda menjadi aspek yang harus diperhatikan sebelum menerima seseorang bekerja di instansi lingkup pemerintah daerah, khususnya terkait self efficacy dan conscientiousness. Hal itu karena kinerja organisasi yang baik berasal dari pegawai yang memiliki kinerja yang baik pula (Robbins dan Timothy 2010), dan salah satu pemicu pegawai pemda memiliki kinerja yang baik adalah self efficacy yang tinggi dan karakter conscientiousness yang dimiliki pegawai pemda itu sendiri. Selain itu, dua karakter tersebut juga mampu membawa impelementasi sistem pengukuran kinerja ke level isomorfisma normatif. Untuk masa mendatang, implementasi sistem pengukuran kinerja harus segera diintegrasikan dengan perangkat sistem informasi agar dapat membantu dan mempermudah pelaksanaan SAKIP dan pelaporan LAKIP.

Penelitian ini memeiliki keterbatasan yang akan memengaruhi hasil penelitian. Keterbatasan-keterbatasan itu antara lain: pertama, item-item yang terdapat dalam kuesioner penelitian banyak yang di-drop, sehingga pengukuran-pengukuran yang dipakai untuk menjelaskan konstruk yang dibangun kurang maksimal. Ketiga, data penelitian ini merupakan hasil dari instrumen yang berdasarkan pada persepsi responden, maka hal ini dapat menimbulkan masalah jika per- sepsi responden berbeda dengan keadaan sesungguhnya. Keempat, pengukuran variabel kesesuaian tugas dengan kompetensi pendidikan (KTdK) hanya dilakukan dengan pendekatan pembobotan, yakni memberikan bobot ' 1 ' jika posisi responden tidak sesuai dengan latar belakang pendidikan, dan bobot '2' jika posisi responden sesuai dengan latar belakang pendidikan. Pendekatan yang merupakan pengembangan dari peneliti sendiri ini sangat mungkin memiliki kelemahan.

Kelima, penelitian ini hanya dilakukan di lingkup wilayah Provinsi Daerah Istimewa Yogyakarta, sehingga kurang mampu mengeneralisasi praktik-praktik pengukuran kinerja secara luas, khususnya di Indonesia. Keenam, wawancara kepada responden hanya dilakukan di tujuh SKPD berbeda. Padahal, setiap SKPD memiliki karakter dan tugas yang spesifik, sehingga hasil wawancara tidak bisa dijadikan dasar sebagai simpulan apa yang terjadi di seluruh SKPD yang menjadi sampel penelitian. Terakhir, jumlah sampel pada tahap survei jika dibandingkan dengan jumlah sampel minimal yang dibutuhkan untuk menguji model persamaan struktural sangat jauh dari ideal (97 berbanding 212 sampel). Hal ini disebabkan jumlah sampel yang ada di lapangan memang terbatas dan ditambah lagi respon rate di lapangan yang relatif rendah.

Beberapa masukan yang direkomendasikan untuk pengembangan penelitian berikutnya, yaitu; pertama, peneliti berikutnya dapat mencari faktor-faktor lain yang dapat menangkap fenomena isomorfisma dalam kaitannya dengan implementasi sistem pengukuran kinerja. Kedua, penelitian selanjutnya sangat disarankan untuk dilakukan di pemda selain lingkup DIY atau bahkan memperluas wilayah penelitian hingga ke seluruh pemda di Indonesia, agar dapat memberikan hasil yang memiliki validitas eksternal lebih baik. Ketiga, penelitian selanjutnya yang memasukkan variabel kesesuaian tugas dengan kompetensi pendidikan (KTdK) sebaiknya tidak melakukan pengukuran variabel tersebut hanya dengan pendekatan pembobotan, tetapi sebaiknya berdasarkan pengukuran yang lebih baik yang bisa saja bersumber dari penelitian lain. 
Keempat, penelitian selanjutnya sangat diharapkan untuk mencukupi aturan sampel ideal agar hasil pengujian hipotesis menunjukkan hasil yang lebih baik. Terakhir, penggunaan mixed methods sangat disarankan bagi penelitian berikutnya, karena dengan menggunakan teknik ini, maka hasil yang diperoleh dapat digali lebih dalam dan dapat melihat dari sudut pandang yang beragam dan kaya dibandingkan apabila hanya menggunakan satu analisis saja. Disamping itu, penggunaan strategi lain, seperti: eksploratoris sekuensial, transformatif sekuensial, triangulasi sekuensial dapat dipertimbangkan untuk dimanfaatkan kebaikan metodanya.

\section{DAFTAR REFERENSI}

Akbar, R., P. Robyn., dan P. Brian. 2012. Performance measurement in Indonesia: The Case of local government. Pacific Accounting Review 24 (3): 262-291.

Artley, W., dan S. Stroh. 2001. The performance-based management handbook. Establishing and maintaining a performance-based management program, 21-26.

Bandura. 1997. Self-efficacy; The exercise of control. W. H. Freemand and Comapany.

Berry, A. J., A. F. Coad., E. P. Harris., D. T. Otley., dan C. Stringer. 2009. Emerging themes in management control: A review of recent literature. The British Accounting Review 41 (1): 220.

Braun, V., dan V. Clarke. 2006. Using thematic analysis in psychology. Qualitative Research in Psychology 3: 77-101.

Cavalluzzo, K.S., dan C. D. Ittner. 2004. Implementing performance measurement innovations: Evidence from government. Accounting, Organizations and Society 29: 243-267.
Chin, W. W. 1998. Issues and opinion on structural equation modeling. MIS Quarterly 22 (1): 1-14.

Chin, W. W., B. L. Marcolin., dan P. R. Newsted. 2003. A Partial least squares latent variable modeling approach for measuring interaction effects: Results form a monte carlo simulation study and voice mail emotion/adoption study. Information Systems Research 14 (2): 189-217.

Collins, R. 1979. The credential society. New York: Academic Press.

Creswell, J. W. 2010. Research design: Qualitative, quantitative and mixed methods approaches. California: Sage Publication.

DiMaggio, P. J., dan W. W. Powell. 1983. The Iron cage revisited: Institutional isomorphism and collective rationality in organizational fields. Dalam W. W. Powell dan P. J. DiMaggio (editor). The New institutionalism in organizational analysis (p/ 63-82). Chicago: The University of Chicago Press.

Falk, R. F., dan N. B. Miller. 1992. A primer for soft modeling. University of Akron Press.

Fennell, M. L. 1980. The effects of environmental characteristics on the structure of hospital clusters. Administrative Science Quarterly 25 (3): 484-510.

Guadagno, R. E., B. M. Okdie., dan C. A. Eno. 2007, Who blogs? Personality predictors of blogging. Computer in Human Behavior 24 (5): 1993-2004.

Gudono. 2014. Teori organisasi edisi 3. Yogyakarta: BPFE-Yogyakarta.

Hartono, J., dan Abdillah. 2009. Konsep dan aplikasi PLS (Partial Least Square) untuk penelitian empiris. Yogyakarta: BPFE Yogyakarta.

Hair, J. F., C. W. Black., B. J. Babin., R. E. Anderson., dan R. L. Tatham. 2006. Multivariate data analysis (Vol. 6). 
Upper Saddle River, NJ: Pearson Prentice Hall.

Hartono, J. 2010. Metodologi penelitian bisnis

- Salah kaprah dan pengalamanpengalaman (Edisi pertama). Yogyakarta: BPFE Yogyakarta.

Henseler, J., C. M. Ringle., dan R. R. Sinkovics. 2009. The Use of partial least squares International marketing. Advances in International Marketing 20: 277-319.

Ittner, C.D., D. F. Larcker., dan T. Randall. 2002. Performance implications of strategic performance measurement in financial services firms. Working paper, University of Pennsylvania and University of Utah.

Julnes, P. L., dan M. Holzer. 2001. Promoting the utilization of performance measures in public organization: An Emprirical tudy of factors affecting adoption and implementation. Public Administration Review 61 (6): 693 708.

Johnson R. B., dan A. J. Onwuegbuzie. 2004. Mixed methods research: A Research paradigm whose time has come. Educational Researcher 33 (7): 1426.

Kloot, L. 1999. Performance measurement and accountability in Victorian Local Government. The International Journal of Public Sector Management 12 (7): 565-583.

Korzaan, M. L., dan K. T. Boswell. 2008. The influence of personality Traits and information privacy concerns on behavioral intentions. Journal of computer information systems 48 (4): 15.

Lai, M., dan S. L. Fan. 2008. Use of fit perception in employee behavioral criteria in Taiwan IT industry. Business and Information 5 (1). Available also at, http://academic-papers.org/ocs $2 /$ session/Papers/A2/234.doc.

Larson, M. S. 1977. The rise of professionalism: A Sociological analysis. Berkeley: University of California Pres.

Lee, C., dan P. Bobko. 1994. Self efficacy belief: Comparation of measures. Journal of Applied Psychology 60: 187-191.

March, J. G., dan J. P. Olsen. 1976. Ambiguity and choice in organizations. Bergen, Norway: Universitetsforlaget.

McClelland, D. C. 1973. Testing for competence raher than intellegence. American Psychologist 28 (1): 1-14.

McCrae, R. R., dan P. T. Costa. 1986. Clinical assessment can benefit from recent advances in personality psychology. American Psychologist 41 (9): 10011003.

McElroy, J.C., A. R. Hendrickson., dan A. M. Townsend. 2007. Dispotional factors in internet use: Personality versus cognitive style, MIS Quarterly 31 (4): 809-820.

Meister, J. C. 1998. Corporate universities in building a world class work force. New York: McGraw-Hill, Inc.

Meyer, J. W., dan B. Rowan. 1977. Institutionalized organizations: Formal structure as myth and ceremony. American Journal of Sociology 83 (2): 340-363.

Nurkhamid, M. 2008. Implementasi inovasi sistem pengukuran kinerja instansi pemerintah. Jurnal akuntansi pemerintah 3 (1): 45-76.

Pfeffer, J. 1982. Organizations and organization theory. Boston: Pitman.

Robbins, S. P. 1998. Organizational behavior: Foundation, realities, dan challenges. $2^{\text {nd }}$ edition. New York: McGraw Hill.

Robbins, S. P. Dan A. J. Timothy. 2010. Organizational behavior (14th Edition). New Jersey: Prentice Hall. 
Scott, R. W. (1998). Organizations : Rational, natural, and open system (4th ed.). Upper Saddle River, New Jersey: Prentice Hall.

Sholihin, M. dan D. Ratmono. 2013. Analisis SEM-PLS dengan Warp PLS 3.0 untuk hubungan nonlinier dalam penelitian sosial dan bisnis. Yogyakarta: Penerbit Andi.

Sihaloho, F. L., dan A. Halim. 2005. Pengaruh faktor-faktor rasional, politik dan kultur organisasi terhadap pemanfaatan informasi kinerja instansi Pemerintah Daerah. Simposium Nasional Akuntansi VIII Solo.

Sofyani, H., dan R. Akbar. 2013. Hubungan faktor internal institusi dan implementasi sistem akuntabilitas kinerja instansi pemerintah (Sakip) di Pemerintah Daerah. Jurnal Akuntansi dan Keuangan Indonesia 10 (2): 184-205.

Supangat, A. 2007. Statistika: Dalam kajian deskriptif, inferensi, dan nonpara- metrik. Edisi Pertama. Jakarta: Kencana Prenada Media Group.

The Urban Institute. 2002. How and why nonprofits use outcome information. The Urban Institute, Washington, D.C.

Tolbert, P. S., dan L. G. Zucker. 1983. Institutional sources of change in the formal structure of organizations: The Diffusion of civil service reforms. 1880-1 935. Administrative Science Quarterly 23: 22-39.

Vinzi, V. E., W. W. Chin., J. Henxeler., dan H. Wang. 2010. Handbook of partial least squares: Concepts, methods and applications. Springer Handbooks of Computational Statistics.

Wijaya, A. H. C., dan R. Akbar. 2013. The influence of information, organizational objective and targets, and external pressure toward the adoption of performance measurement system in public sector. Journal of Indonesian Economy and Business 28: 62-83.

\footnotetext{
${ }^{1}$ Responden ini juga menyampaikan bahwa pimpinan (kepala dinas) di tempatnya bekerja memiliki komitmen yang sangat kuat. Lebih lanjut beliau menyampaikan bahwa pimpinannya sangat menghargai waktu, aspirasi masyarakat dan menjunjung tinggi amanah untuk mencapai kinerja organisasi guna memenuhi kepuasan masyarakat.

${ }^{2}$ Responden menunjukkan mimik setengah menyesali situasi ini. Dalam penjelasan lebih lanjut yang tidak dipaparkan pada paper ini, responden secara implisit sesungguhnya ingin menyatakan bahwa yang mengalami hal tersebut adalah dirinya sendiri. Perlu diketahui responden ini adalah seorang Master alumni perguruan tinggi di Belanda di bidang tata kota dan sub urban. Dari paparannya, responden ini merasa tidak diposisikan dengan ideal dan tidak diberi ruang improvisasi yang memadai. Ia juga menyayangkan bahwa beberapa kebijakan lebih banyak didminasi kepentingan politik ketimbang kebutuhan masyarakat.

${ }^{3}$ Argumen ini berdasarkan hasil wawancara dengan responden asal kabupaten Sleman.

${ }^{4}$ Perlu diketahui bahwa responden ini adalah pegawai yang kompetensi lulusan dan tugas pekerjaannya tidak sesuai. Namun, ia sudah memiliki pegalaman kerja yang lama yakni 20 tahun. Catatan tambahan ini perlu penulis tambahkan agar pembaca mengetahui situasinya.

${ }^{5}$ Dari dealektika intonasi responden saat menyampaikan opininya, responden Nampak bersemangat dengan bersikap sangat kritis terhadap situasi ini (ketidak sesuaian tugas dengan kompetensi aparat pemda). Ia juga menyampaikan bahwa ketika diangkat, posisi responden tersebut sesuai dengan komepetensinya dan ia sangat puas dengan kondisi tersebut. Ia menjadi bersemangat dalam bekerja da nada niat yang kuat untuk mencapai kinerja. Namun, ketika rolling jabatan terjadi, dia merasa posisi saat ini (kasubbag dinas perhubungan) tidak sesuai dengan kompetensinya. Sehingga, ia mengakui bahwa dalam pekerjaannya ia hanya menjalankan apa yang sudah ditugaskan semampunya. Ia merasa kehilangan semangat, kecintaan pada pekerjaan, kepuasan dan niat yang kuat untuk mencapai kinerja.
} 